\title{
MORAL VALUE OF IJARAH AND UJRAH: REVIEW OF RAHN CONCEPT IN ISLAM
}

\author{
Lenny Yanthiani \\ Sekolah Tinggi Ekonomi dan Bisnis Islam Al Jabar Bandung, Indonesia \\ Email: lenny.yanthiani@stebi-aljabar.ac.id
}

\begin{abstract}
Nowadays, Islamic pawning products have developed quite rapidly. In its operation, Islamic pawn products generally used the ijarah contract system. ljarah agreement is a contract in the form of transferring the right to use goods and / or services through payment of rental wages, without being followed by the transfer of ownership of the goods themselves. In running a sharia pawn business, both Sharia Commercial Banks (BPRS), Sharia Rural Banks and also Islamic Pawnings were always guided by the fatwa of the National Sharia Board, which is a supervisory institution for Islamic and non-bank sharia financial institutions formed by the Indonesian Ulama Council (MUI).

Therefore, this study aimed to describe and analyze the concept of ijarah and the aspects of ujrah in the realm of sharia pawnshop (rahn) especially in terms of how the benefits derived from a rahn product. The methodology used a qualitative approach (qualitative research), with a deductive style (deductive method). The results were in line with the fatwa of the National Sharia Council (DSN) no. 25 / DSN-MUI / III / 2002 which stated that the amount of storage service fees should not be determined based on the loan amount. The product organizers could only get benefit from the lease fees collected. This then constitutes the principles and values contained in the ijarah agreement and the ujrah aspects in the sharia pawnshop review (rahn).
\end{abstract}

Keyword: Rahn, ljarah, Ujrah, Moral Value.

\section{A. INTRODUCTION}

Pawn is one of the categories of debt-based agreements based on the trust of the person who owes, where the person who owes his mortgage mortgages it as collateral for the debt. The collateral remains the person who pawned, but it is controlled by the pawn recipient. This practice has existed since the period of the Prophet and he had also practiced it. So at this point, pawn is an alternative way in liquidity instruments in Islam. Moreover, in the social context, pawn practice has also very high social values. This is because the pawn is applied voluntarily on the basis of helping and upholding the value of trust from both parties. (Rifai, 2002)

Therefore, based on its principles, values and motives perspectives, Sharia pawning products should be a product of Islamic financial institutions that aim to provide easy lending with sharia law principles and to eradicate or reduce non-Islamic practices which are detrimental to the society, which is increasingly rampant in the community and makes people's lives burdensome because it was built with a system that is very detrimental.

In order to support the realization of this, reinforcement is needed, especially on the foundation of the Islamic pawn, and one of the most important aspects is the contract that is used. One of the contracts that are generally used in the realm of Islamic pawn is the ijarah contract, which includes the stipulation of the ujrah as an important aspect in the implementation of the ijarah contract in the context of the Islamic pawn. 
Referring to the close relationship of ijarah, ujrah and its application in the context of Sharia pawn (rahn), the writer intends to review the relationship between the three and provide a comprehensive overview, especially related to the values contained in the contract. So that we can see better the added value given by Islam through the concept of ijarah and ujrah in realizing the objectives of the implementation of Sharia pledge, especially in the system of obtaining profits from a sharia pawning product.

\section{B. METHOD}

The method used in this study used a qualitative approach (qualitative based research), by using the method of deductive thinking (deductive method), which analyzed the phenomena of general knowledge or general facts to find specific conclusions. The study of literature used the study of literature by analyzing and synthesizing a variety of views and opinions of experts or the results of previous studies, for the next formulation of the concept being discussed is taken.

Literature review used in this study was used by finding previous literature related to the theme to be presented, which was then collaborated with the writer's thoughts to find a form of conceptual understanding that could provide information for the wider community in general and for writers in particular about the themes discussed.

The research process began by reviewing the formulation of the problem that formed the basis of this research, i.e. in the context of ijarah and ujrah whether the implementation of the ijarah principle in the practice of deposit service tariffs in Sharia pawn providers was in accordance with the fatwa and provisions issued by the DSN and how the views Islamic law on the implementation of the application of the ijarah contract principle and the applicable ujrah aspects in Indonesia in general are. Furthermore, the problem was examined with a literary and literary approach, so as to produce a research conclusion as an answer to the research problem.

\section{RESULT AND DISCUSSION}

\section{Basic Law of ljarah and Ujrah}

\section{a. Al-Qur'an}

The legal basis or legal form for ijarah in the Quran is contained in several verses, including: First, QS: AtThalaq which states, 'If they feed you (children) for you, then give them their reward, and deliberate among you (all things) well; and if you encounter difficulties then another woman may suckle (the child) for her. (Ministry of Religion of the Republic of Indonesia, n.d., p.188); Secondly, QS: Al-Qashash which says, 'One of the two women said: "Yes, my father, take him as a person who works (for us), because surely the best person you take to work (for us) is someone the strong can be trusted again ". (Asiyah, 2014)

Based on the verses of the Quran above, in Islam, the principles of wages must consider aspects of fulfilling obligations towards others rather than obtaining individual rights as stated in the first verse; in the second paragraph the wage must be in line or in line with the individual quality or skills of each employee. In a modern context, a person's salary is adjusted to the workload, abilities and expertise, and professionalism of the individual. (Saepudin, et al, 2017, p.57)

\section{b. Hadith of the Prophet Muhammad PUBH}

In addition to the Quran, the traditions of the Prophet Muhammad also gave many signs of the importance of fulfilling wages in the ijarah agreement. Even in some of his traditions, the Prophet (PBUH) emphasized how 
important this aspect of ujrah was in the implementation of work relations and in the context of bringing about justice between the two parties.

The following are some of the most commonly used traditions related to the concepts of ujrah and ijarah. First, in the narration of Ibn Majah's history from Ibn Umar, that the Prophet Muhammad said: 'Give the worker's wages before his sweat is dry;' Second, in the hadith of the history of Abd. Razaq from Abu Hurairah, that the Prophet Muhammad also said: 'Whoever employs workers, let them know their wages; and Third, in the narration of the narration of Abu Dawud from Saad bin Abi Waqqash, that the Prophet Muhammad said: 'We once rented land with (paid) agricultural produce, so the Prophet forbade us to do that and ordered that we rent it with gold or silver. '(al-Qazwiniy, ttp817)

\section{c. ljma ulama about the ability to do a lease agreement (ljarah).}

In the case of muamalah figh approach, we also find several rules and figh laws that explain the concept of ujrah and ijarah. An understanding of this approach is also important, given the study of muamalah fiqh themes will always be related to these rules. In the perspective of fiqh muamalah, here are a few things that form the basis of law and matters relating to the concept of ijarah.

In terms of fiqh rules, the concept of ijarah is based on the rule, "Basically all forms of muamalah are permissible unless there is an argument forbidding it." On the basis of these rules, the scholars agree (ijma) that the ijarah contract becomes permissible in accordance with the original law, as long as the ijarah is in accordance with the principles of the Shari'a. And conversely, when the principles it uses are contrary to Islamic law, then the muamalah contract or transaction automatically becomes forbidden, as stated in the above rules. To the best of the author's knowledge, almost all schools of fiqh allow this kind of ijarah transaction.

\section{Concepts and Conditions of ljarah and Ujrah}

\section{a. Definition}

The word al-ijarah itself comes from the word al-ajru which means al-'iwadhu which means "replace", al-kira', which means "together" and al-ujrah which means "wage". In terminology, ijarah is a type of muamalah activity based on the value of expediency. For example: leasing, contracting or buying and selling other services. In the perspective of the ulema of the schools, each school defines a different definition of this ijarah. However, in principle they argue that the ijarah contract is a transaction contract due to the exchange of benefits and a certain reward. In general, the definition can be taken from the opinions of the school of Islamic scholars who are not, either Shafi'i, Hanafi or Maliki. (Haroen, 2007)

In practice, the ijârah contract which is generally used in Sharia financial institutions is the transfer of use rights over goods and or services through payment of rental wages, without being followed by the transfer of ownership of the goods themselves. Through this contract, it is possible for the pawnshop to withdraw the rent for the storage of movable property belonging to the customer who has made the contract.

ljârah contract is the use of benefits or services in exchange for compensation. The owner who rents out the benefits is called Muajjir, while the tenant (the customer) is called Râhin, as well as something for which the benefits are taken (day care) is called major with compensation or remuneration called Ajan or Ujrah. Thus the customer will provide a service fee or fee to Murtahin, because the customer has left the goods with Murtahin to guard or care for Marhun. Therefore, through the use of this ijârah contract, the customer will only provide a fee / service save to Murtahin, if the ijârah contract period has ended and Murtahin returns it 
to Râhin, therefore the Sharia Pawnshop becomes the right media to be used and functioned as well as the media safety of customer's goods. (Rais, 2006)

Based on some of the above meanings, it can be concluded that in the case of aqad ijarah there are three main elements. They are: first, the elements of the parties making the transaction, namely the employer and the worker. Second, the elements of the agreement namely ijab and qabul, and the third, the material elements agreed upon, in the form of work and ujrah or wages.

The ujrah etymologically means rewards for services or wages. Derivatively, this word is taken from the verb 'ajara - ya' jiru - ajran 'which means the general meaning of wages or replies. (Huda, 2011) From the word ajran, then forms the word' ujrah 'or wages. This is because this word is equivalent to the word 'iwadh' which means a substitute for something. Therefore, if we reduce the understanding in the current context, the determination of the ujrah is based on the determination of the amount of wages that must be paid on the agreement agreed upon in advance. In this case, we often refer to the agreement with the contract. (Rahman, 2016)

The concept of ujrah in Islamic law belongs to the realm of fiqh muamalah. Ujrah is obtained by a worker as a form of compensation from the employer or employer for the work he has completed. Often also, this ujrah is also categorized in the term ju'alah which means a necessity to do something absolutely as a certain payment for a certain job. Others define ju'alah as an obligation to pay certain wages for heavy work, although the pay is uncertain. In the classification of Islamic law, in line with the current perspective, wages are divided into three levels. They are: minimum wage, highest wage and actual wage. (Rahman, 1995)

In form, the wages must be in the form of mutaqawim mall, which is lawful property to be used. The amount of wages must be clearly agreed by both parties. It is emphasized that in Islam, wages are avoided that are not clear, because they contain an element of jahalah (uncertainty). ljarah with this aspect of ujrah according to jumhur ulama besides al-Malikiyah, is illegal. While fuqaha 'al-Malikiyah determines the validity of the ijarah as long as the intended wage size can be known based on habits (urf).

Sharia pawn (rahn) is to hold one of the customer's assets or rahn as collateral for the debt / loan he has received. The collateral has economic value, so that the party holding or receiving the pawn gets a guarantee to be able to take back all or part of the receivables. (Antonio, 2001) In running a sharia pawning business, as a sharia financial institution based on the fatwa of the National Sharia Board (DSN) which is the supervisor of sharia bank and non-bank financial institutions formed by the Indonesian Ulama Council (MUI). So among the functions of the DSN is to make Guidelines for Sharia Products taken from Islamic legal sources. (Anshori, 2006)

DSN Fatwa which is directly related to Islamic Pawn products is DSN Fatwa No. 25 / DSN-MUI / III / 2002 concerning Pawn (rahn) and DSN Fatwa No. 2625 / DSN-MUI / III / 2002 concerning gold. Therefore, currently the Sharia Pawning only serves one type of contract, ijârah (rental services for safekeeping goods). One of the contents of the provision on rahn is that the amount of maintenance and storage costs must not be determined based on the loan amount. This side is the main concern in this research later.

\section{b. Types, Rules, Conditions, Rukn (Pillars) and Objects of ljarah}

As an activity that is legitimized by the Sharia, then of course this ijarah cannot be separated from the provisions that indicate whether or not the activity is valid in terms of Islamic law (figh). Therefore, it becomes important and necessary to explain these provisions, especially those relating to the types, rules, conditions, rukn and objects of the ijarah as a basic instrument in understanding the concept of ujrah and ijarah and in the context of their application in the lease agreement at the institution Islamic pawn. 
In Islamic law there are two types of ijarah, namely:

1) ljarah related to service rent, i.e. hiring someone's services for a fee in return for rented services. The employer is called mustajir, the worker is called ajir and the wages paid are called ujrah; and

2) ljarah relating to the leasing of an asset or property, i.e. transferring the right to use from a particular asset or property to another person in return for rental fees. This form of ijarah is similar to leasing in conventional businesses. The lessee is called mustajir, the lessor is called mu'jir / muajir and the rental fee is called ujrah.

At this point, we see that the terminology of ijarah is always contained in the ujrah aspect. If ijarah is an activity, then ujrah is the result or reward for the activity. The first form of ijarah is widely applied in sharia banking services, while the second form of ijarah is commonly used as a form of investment or financing in sharia banking. (Nurhayati, 2008). In order to ensure that the ijarah is in accordance with Islamic law. Then the boundaries are made so that they become a means of control in the implementation of the ijarah contract, hereinafter referred to as the ijarah rule. The rules in ijarah are generally as follows:

1) All goods can be benefited without reducing the substance of the goods, the goods can be rented.

2) All goods which are used little by little but do not reduce the substance of the goods such as milk on camels and water in wells can also be rented out.

3) Money from gold or silver and cannot be rented out because these items after consumption become lost or used up.

Another important thing in the implementation of a contract is understanding the terms, conditions, and provisions of the object of goods that can be subject to ujrah in the ijarah contract. Based on this, in terms of conditions, the conditions of ijarah that must exist in order to fulfill the provisions of Islamic law related to ijarah are as follows:

1) The services or benefits to be provided by the leased asset must be certain and clearly known by both parties.

2) Ownership of fixed assets to the lessee who is responsible for their maintenance, so the asset must be able to benefit the lessee.

3) The ijarah agreement is terminated when the asset concerned ceases to provide benefits to the lessee. If the asset is damaged in the contract period, the ijarah contract will still apply.

4) Assets may not be sold to tenants at a price determined before the contract ends. If the asset is to be sold, the price will be determined when the contract expires. (DSN, n.d., p.55)

While from the side of the rukn or pillars, at least the following pillars must be met:

1) Mu'jir and Musta'jir, that is, those who carry out a rental agreement or wages. Mu'jir are those who give wages and those who rent out, while Musta'jir are people who receive wages for doing something and who rent something. Required in Mu'jir and Musta'jir is baligh, understanding, capable of doing tasharuf (controlling wealth), and mutual respect. This is based on the word of Allah SWT: 'O people of faith, do not eat your neighbor's wealth by way of vanity, except by the way of business that applies with mutual liking among you. And do not kill yourself; surely Allah is Most Merciful to you. '(Qur'an, 29: 29). In addition, ijarah people are also required to know the benefits of goods that are stored perfectly so that they can prevent disputes. 
2) Sighat ijab kabul between Mu'jir and Musta'jir, ijab kabul of rent and wage.

3) Ujrah, required by both parties to know the amount, both in leasing or in terms of wages.

4) Goods that are rented or something that is done in the context of wage, are required on goods that are rented with the following conditions.

a) The goods which are objects for rent and wages can be utilized.

b) Objects which become objects of rent and wages can be handed over to the tenants and workers along with their uses (specifically in the rent).

c) The benefits of the object being rented is a case that is permissible (permissible) according to the Sharia is not prohibited.

d) The object for rent is required to be eternal in substance until the time specified according to the contract agreement. (Ascarya, 2007)

Finally, in terms of the provisions of the ijarah object, it is necessary to be known by the parties making the ijarah agreement that the object must contain the following conditions:

1) ljarah objects are the benefits of using goods and / or services.

2) The benefits of goods or services must be assessed and can be implemented in a contract.

3) The benefits of goods or services must be permissible (not prohibited).

4) The ability to meet the benefits must be real and in accordance with sharia.

5) Benefits must be identified specifically in such a way as to eliminate mischief (ignorance) which will result in a dispute.

6) Benefits specifications must be clearly stated, including the time period. Can also be recognized by specifications or physical identification.

7) Rent or wages is something that is promised and paid by the customer to LKS as payment of benefits. Something that can be used as a price (tsaman) in buying and selling can also be used as rent or wages in ijarah.

8) Payment of rent or wages may be in the form of services (other benefits) of the same type as the object of the contract.

9) Flexibility in determining rent or wages can be realized in terms of time, place and distance.

These rules and provisions are, in the end, derived from Islamic principles and values related to the concept of ijarah and ujrah as important instruments for leasing and buying and selling benefits that are commonly used in the Sharia mortgage. This is as a differentiator that transactions in rahn or Sharia pledge are justified on the basis of the earlier loot and ujrah. This is because, experts have different opinions regarding the benefit of this pawn service. Is the guarantor or the collateral? Islamic values contained in the concept of ijarah and ujrah then become a middle ground over the possibility of taking advantage of the pawned goods, as explained by the concept of ijarah and ujrah in the previous section. (Zuhaili, 1984)

\section{c. Other obligations and provisions regarding ijarah, ujrah in rahn.}


In addition to the provisions relating to the terms, rukn (pillars) and provisions of the object in the ijarah contract, there are also some things that need to be known by the parties making the ijarah agreement, namely understanding the rights and obligations that bind both parties in the ijarah agreement. In terms of the requirements of the obligations of the giver of the benefits of the goods or services, here are some things that must be known by the party. They are:

1) Providing goods that are rented or services provided

2) Bear the cost of maintaining goods.

3) Guarantees if there is a defect in the leased item.

In terms of the obligations of beneficiaries of goods or services, the following things need to be considered by these parties. They are:

1) Pay rent or wages and are responsible for maintaining the integrity of the goods and using them according to the contract (contract).

2) Bear the cost of maintaining goods that are lightweight (not material).

3) If the leased item is damaged, not because of a violation of permitted use, nor is it due to the negligence of the beneficiary in safeguarding it, he is not responsible for the damage. (Anwar, 2007)

As for the terms of the ujrah (fee, payment of rent) which are usually contained in an ijarah agreement, the criteria for the conditions include the following:

1) Must be included from halal property

2) The type, type and unit must be known

3) Must not be of the same type as the benefit to be rented to avoid the similarity of usury Fadl.

4) Most scholars allow ijarah fees not with money but in assistance (other benefits). For example, paying 1-week car rental by teaching their children mathematics for 1 month 8 times a meeting.

Principally, the ijarah contract must clearly state who is responsible for maintaining the assets of the leased object. Some scholars state that if the lease contract mentions the cost of repairs borne by the lessee, the lease contract is invalid, because the lessee incurs unclear costs. In the case of cancellation and termination of the ijarah, the parties involved in the ijarah agreement need to pay attention to the following. In principle, ijarah is a type of contract that does not allow fasakh on one of the parties, because ijarah is a contract of exchange, except when there are things that require fasakh. ljarah will be fasakh (canceled) if there are things as follows:

1) There is a defect in rented goods that occur at the hands of the tenant.

2) Goods for rent are destroyed or damaged.

3) Damage to the items being paid, such as clothes being waged for sewing.

4) The ijarah agreement is terminated when the asset concerned ceases to provide benefits to the lessee.

5) Fulfillment of the benefits accrued, the expiration of a predetermined period and the completion of work.

6) One party dies (Hanafi); if the leased item is in the form of an animal then his death ends the ijarah contract (Jumhur). 
7) Both parties cancel the contract with iqolah. (Sabiq, 1987)

If the ijarah has ended, the tenant is obliged to return the leased property, if the item can be moved, he is obliged to surrender it to the owner, and if the form of the leased item is a permanent object, he is obliged to return it empty, if the rental object is land, he is obliged to surrender to its owner in the empty state of the plant, except when there are difficulties to eliminate it (Fadhlan, 2014)

The Hanbali school believes that when the ijarah has ended, the tenant must release the rented goods and there is no need to return to surrender, such as safekeeping. Meanwhile, according to Hanafiyah, it ended with the death of one of the two people who had an ijarah agreement, only the right of benefit, then this right could not be inherited because the inheritance was valid for the possessed property. While Jumhur Ulama is of the opinion that the ijarah is not canceled due to the death of one of the parties in the agreement.

\section{CONCLUSION}

The results of in-depth analysis and research related to ijarah relations, ujrah in its application in Sharia pawning products shows that the relationship between the three is in line and in accordance with the principles of ijarah in Islamic financial institutions in accordance with DSN fatwa No. 25 / DSN-MUI / III / 2002 which stated that maintenance and storage costs should not be determined based on the loan amount but based on the estimated amount. Then as a form of appreciation to customers of Islamic financial institutions are entitled to issue a discount policy on the storage service rates. This principle is a formula derived from the values contained in the ijarah and ujrah contracts.

In short, these values become a reference that the storage service tariff in Islamic financial institutions must be in accordance with the principles of Islamic law, which is permissible in Islam, voluntary, carrying value maslahah and justice for the wider community which is a derivative of the principles and values contained in ijarah and ujrah. The results also concluded that the basic principles (standards) of minimum ijarah financing that must be required are as follows: (1) In an ijarah agreement, the physical of the leased commodity remains in the ownership of the renting and only the benefits are transferred to the lessee. Something that cannot be used without consuming it cannot be rented out, such as money, food, fuel and so on. Only assets owned by the lessee can be leased, unless permitted sub-lease (leasing back the leased object assets) in the agreement allowed by the lessor; (2) Until the time when the object of the leased object is sent to the lessee, the rental fee cannot be used yet; (3) During the rental period, the lessee must remain in control of the object of lease and assume all risks and returns from ownership. However, if there is damage or loss of assets of the rental object due to the tenant's mistake or negligence, the consequences are borne by the lessee; (4) Leases can be terminated prematurely, but only with the agreement of both parties.

\section{REFERENCES}

Anshori, Abdul Ghafur. (2006). Syari'ah Pawn in Indonesia (Concept, Implementation and Institutionalization). Yogyakarta: Gadjah Mada University Press.

Antonio, Muhammad Syafi. (2001). Sharia Bank from Theory to Practice. Jakarta: GIP, cet.to-1

Anwar, Syamsul. (2007). Sharia Agreement Law (Study of the Theory of Covenants in Muamalat's Jurisprudence). Jakarta: Raja Grafindo Persada.

Anwar, Syamsul. (2007). Sharia Agreement Law. Jakarta: PT. Grafindo Persada.

Asiyah, Binti Nur. (2014). Sharia Bank Financing Management. Yogyakarta: Terrace. 
Basyir, Ahmad Azhar. (2000). Muamalat's Legal Principles. Yogyakarta: UII Press.

Basyir, Ahmad Azhar. (1983). Islamic Law Regarding Riba, Debt and Pawn Receivables. Bandung: AlMa'arif.

Fadhlan (2014). Muamalah's Jurisprudence Perspective and Its Application in Banking. Iqtishadia Journal, Vol. 1, No.1, June.

Haroen, Nasroen. (2007). Fiqh Muamalah. Jakarta: Primary Media Style.

Huda, Qomarul. (2011). Fiqh Muamalah. Cet.1. Yogyakarta: Terrace.

National Sharia Board. (2002). National Sharia Council Fatwa (DSN) no. 25 / DSN-MUI / III / 2002.

al-Qazwiniy, Muhammad ibn Yazid Abu Abdillah. (n.d.) Sunan Ibn Majah. Beirut: Dar el-Fikr.

Rahman, Afzalur. (1995). Islamic Economic Doctrine. Translator Soeroyo Nascangin. Jakarta: Daba Bhakti Wakaf.

Rahman, Annisa. (2016). Analysis of the Determination of the Ujrah in Financing with the ljarah Agreement and Its Implications for Profits in BMT Dana Mentari Muhammadiyah Purwokerto. Purwokerto: Faculty of Islamic Economics and Business, IAIN Purwokerto.

Rifai, Moh. (2002). Islamic Banking Concepts. Semarang: CV. Wicaksana.

Sabiq, Sayyid. (1987). Fikih Sunnah 13. Bandung: PT. Al Maarif.

Saepudin, Encep \& Mintaraga Eman Surya. (2017). The Model of Work Productivity in Perspective of the Quran, Journal of Islamadina, Vol.XVIII, No.1, March.

Suhendi, Hendi. (2002). Figh of Muamalah. Jakarta: Raja Grafindo Persada.

Zuhaili, Wahbah. (1984). Al-Figh al-Islami wa Adillatuhu. Volume V. Beirut: Dar el-Fikr. 